\title{
From Gardens of Knowledge to Ezbekiyya after Midnight: The Novel and the Arabic Press from Beirut to Cairo, 1870-1892
}

\section{ELIZABETH M. HOLT}

\begin{abstract}
Late 19th-century Beirut and Cairo were capitals of Arabic literary production and press activity. A period, oft deemed a nahdah, that witnessed the advent of the novel form or riwayyah in Arabic, this was also the moment of intensified French and British imperial involvement in the region, and the concomitant industrialization of Beirut's silk and Egypt's cotton markets. This article argues that, through the novels published in and promoted through the region's burgeoning private journals and newspapers, editors and novelists revived the literary trope of the garden of knowledge as a spatial metaphor for the Arabic reading public. While the 1870s in Beirut began as a hopeful decade-the civil war of 1860 buried in the fortunes being made off Mt Lebanon's mulberry orchards-by 1890s Cairo these Edenic hopes were replaced by a sense of melancholy in the face of rampant speculation, accumulating in the gardens of Ezbekiyya. Reading two novels, Salīm al-Bustān̄̄'s 1870 Al-Huyām fì-jinān al-Shām and Jurjī Zaydān's 1892 Asīr al-mutamahdī, against the literary and press activities of the Bustānī family's Al-Finān, Zaydān's Al-Hilāl, Khalīl al-Khūrī’s Hadīqat al-Akhbār, Yūsuf al-Shalfūn's Al-Zahrah, Muhammad al-Muwaylihị̄s Miṣbāh al-Sharq, and Fāris Nimr and Ya'qūb Sarrūf's Al-Muqtațaf, this article offers a literary history of speculation and capital for late 19th-century Arabic.
\end{abstract}

The Arabic private press and novel form emerged against the rapidly changing forms and flows of late-19th-century capital — cultural, as well as financial and commodity. Both critiquing and producing new habits of consumption, the early Arabic novel circulated within and alongside a number of new Arabic journals and newspapers, read and penned by both men and women. In 1870s Beirut, Salīm al-Bustānī serialized novels in his family's cultural journal Al-finān; the overtones were utopian if also marked by an anxious uncertainty engendered in imagining an emerging reading public of Arabic. By 1890s Cairo, however, as Jurjī Zaydān's Dār al-Hilāl had now made something of a business of publishing novels, many in serial form, the contradictions inherent in Arabic print capitalism ${ }^{1}$ accumulated in the speculative pleasures and dangers afforded by new literary forms, with a newly gas-lit Ezbekiyya standing as a site of a

Elizabeth M. Holt, Bard College, Foreign Languages, Cultures, and Literatures, Campus Road, PO Box 5000, Annandale-on-Hudson, NY 12504-5000, USA. Email: holt@bard.edu 
literary counter-allegory of the nahdah. The gardens of 1870s Beirut's press and its serialized novels, read against those of Zaydān's 1892 novel Asīr al-mutamahdī, evince continuity-in-rupture (to adapt a phrase from Roger Allen) ${ }^{2}$ in this early moment in the history of the novel form.

In 1870, Beirut went from having one newspaper, Khalīl al-Khūrī's official Ottoman Hadìqat al-Akhbār, to becoming a city with a number of important journals and newspapers, publishing on trade, agriculture, industry, history, and science. In addition, 1870 witnessed some of the earliest original serialized riwāya $\bar{a},{ }^{3}$ reviving al-Khūrî̀s own early foray into the genre in 1859 with Way-idhan lastu b-ifranji (Alas, I Am Not a Foreigner), serialized in Hadīqat al-Akhbār from 1859 to 1860. Riwayyah was the term used in Beirut, Cairo and beyond in this period for Arabic prose narrative and plays, regardless of length, generally followed by qualifying adjectives (tarikhiyyah pointing to the historical; gharamiyyah to the romantic; tashkhissiyyah to the theater; with adabiyyah delineating proper comportment, ethics, and increasingly a sense of our own connotations of 'literary'). ${ }^{4}$ In 1859, al-Khūrī deemed his work a riwāyah; in 1870 Beirut, riwāayāt were published in Buțrus al-Bustānī and his son Salīm's journal Al-finān, as well as Yūsuf al-Shalfūn's short-lived satirical journal Al-Zahrah, while in 1890s Cairo Jurjī Zaydān would go on to inherit this literary project, deeming his historical novels riwāyāt. The term riwāyah is more encompassing in this period than an English 'novel,' incorporating the orality of narration as Allen astutely points out, and indeed, as will be argued below, reviving an even older etymology of the term.

The proliferation of periodicals in 1870s Beirut clearly indexes the production of a new kind of readership, ${ }^{5}$ able to pay rather expensive subscription rates, as they became part of a reading public extending far beyond the circles of male Beirutis that formed the core of the literary and scientific societies of 1840s-1860s Beirut, among them Butrus and Salīm al-Bustān̄ī, and Yūsuf al-Shalfūn ${ }^{6}$. The Bustān̄ family published not only Al-Finān, but also the trade journals Al-fannah and Al-funaynah, while the short-lived literary and political journal $A l-N a h l a h$ published briefly in the early 1870 s. Later in the decade, Jam iyat al-Funūn (The Society of the Arts), founded in 1875 and modeled after earlier literary and scientific societies, would publish Thamarāt al-Funūn. Fāris Nimr and Ya'qūb Șarrūf would begin publishing their scientific and later also literary journal Al-Muqtataf the next year in Beirut, before relocating to Cairo in 1884.

In the 1870 s and for years to come, Arabic journals such as the Bustāni family's highly regarded Al-Finān and Nimr and Șarrūf's Al-Muqtataf would be sent by post to readers living not only in Beirut, but in Mt Lebanon, Damascus, Baghdad, Cairo, Alexandria, Yafa, Tunis, and eventually Calcutta, Paris, London, New York, Rio and Buenos Aires. Although Al-finān in its first years published lists of those who had paid their subscriptions, it was anything but clear to the editors and authors of the time who precisely their readers were, what kinds of formal and informal literary educations would inform their reception of the new riwāya erary and themselves. Journals were read and re-read, both silently and aloud, by members of households and networks of friends connected through a literacy in Arabic, including not only fathers and sons, but the educated mothers and daughters so debated in the Arabic press's early years, not to mention the many literate servants who frequently appear in novels from this period, as well as those standing at the thresholds listening in.

In 1870, Adelaide al-Bustān̄̄ (daughter of Buṭrus, and sister to Salīm) ${ }^{7}$ published a short story entitled 'Hanrī wa Amīliyā,' which was serialized over two issues of Al-finān. This fascinating two-installment riwāyah, like several of Salīm's own (not to mention 
Alf laylah wa-laylah), featured a scene of cross-dressing, suggesting both a hope and an anxiety about gender and mobility. 'Hanrī wa Amîliyā' ends with the author leaving behind her characters - the gendered anxiety now narratively resolved in one of those marriages so popular in 19th-century fiction-to address the readers of Al-finān:

If there are some ladies joining the gentlemen in reading Al-finan [the gardens], the gentlemen deserve to have something of the fine, fair pen of the ladies and ha - the gate of al-Jinan is opened to the ladies. ${ }^{8}$

There is a pun here, as the title of the journal Al-Finān is played upon as so many gardens awaiting ladies and their pens. ${ }^{9}$

Indeed, all of the journals so far mentioned in this article play upon this garden themethere are the gardens of Al-finān, the paradise-like garden of Al-fannah, and that little garden of Al-funaynah, all curated by their gardeners, the Bustānī father and son, having joined Hadīqat al-Akhbār, the official garden of Ottoman news, and publishing alongside the flower of Al-Zahrah, and later joined in the fertile field of the Arabic press by the bee of Al-Nahlah, and those fruitful arts and choice clippings discussed in Thamarāt al-Funūn and al-Muqtațf. Reviving a long tradition of figuring compendia of literature and knowledge as gardens, ${ }^{10}$ the serialization of riwāy $\bar{a} t$ in their pages annexes an older etymology for the novel, one Allen treats in passing: 'the Arabic word riwayya is $[\ldots]$ an etymon with a very ancient history. The primary meaning of this root is "to convey water." 11 As irrigation and sea travel were remaking the region's economies, increasingly monocultures-Beirut's of silk, Cairo's of cotton-in the pages of the burgeoning Arabic press ran riwāyāt.

The sense that writing in the new journals of the early Arabic press was something like being in a garden was a notion that Adelaide's father Buṭrus al-Bustānī had pursued in the initial announcement of his journal Al-finān. Circulated in late 1869 and bound as the first page of the first year of Al-Finān, a sense of both belatedness and hopesentiments that provided part of the affective sensibility of the Nahdah-marks Buțrus's vision for Al-finān:

Our language remains without a medium among the great media to spread general knowledge, which includes scientific, literary [adabiyyah], historical, industrial, commercial and civil, in addition to literary pieces and anecdotes, as takes place in foreign countries. Its uses for all [li-l-khạṣ wa-l-iamm] are evident due to its being a means to encourage general knowledge and strengthen its support among the public $[a l-j u m h \bar{u} r]$... Among these gates we open a gate to the possessors of knowledge and a space in which the pen of the skillful among possessors of the pen might circulate.

We have decided to place our trust in God to bring the aforementioned goal into being by publishing a newspaper in the Arabic language entitled Al-finān (the plural of jannah) encompassing the stated benefits, [flowing] from our pen as well as the pens of those who wish to present us with precious selections original or translated in the fields previously mentioned. ${ }^{12}$

This garden trope, aside from the inspired accident of the Bustān 1 family name, indexes a utopian imagining of what the Arabic press and its readers could be that was deeply 
constitutive of the early years of the nahdah. When the Christian-Druze war and ensuing massacres of 1860 had receded to become an earlier generation's nightmare - and before the silk industry had repeatedly disappointed Syrians, before the British had bombarded Alexandria and then occupied Cairo, before the Ottoman empire and the Khedival state had gone bankrupt, indeed before the contradictions of finance capital and industrialized textile production centered in French and British banks, factories and department stores; the orchards, filatures and brokerages of Beirut and Mt Lebanon; and the cotton fields, ginneries and commodity and stock exchanges of Egypt had become broadly legiblewas a moment when the Arabic press in Beirut was flooded with hope and idealism, in a sense a mark of everything that still needed to be negotiated by authors, editors and their readers. In this Edenic early moment in Beirut's press, the gates of the gardens stood open to readers who wished to pick up the pen.

Butrus's announcement for Al-finān, motivated by a pedagogical felt need to spread useful knowledge $l i-l-k h \bar{a} s \underline{s} w a-l-\bar{a} m m$, is marked by the accumulating accretions of definitions of what kind of knowledge is useful. Because if this appeal was to a need, 'as takes place in foreign countries' for more scientific, industrial and commercial knowledge, something that print capitalism's newspapers were seen as uniquely poised to provide, it simultaneously pledged to provide this emerging reading public — not just al-khāș but also al- $\bar{a} m m$ - with the sorts of knowledge that might be found in the long tradition of Arabic adab anthologies, with their emphasis on organizing selections of poetry and prose based on categories that corresponded to the social contexts and topics of discussion and composition in which they would be put to use. Adab in 1870 Beirut contained both the broader, older sense of edified, courtly comportment, as well as our present, narrower use of $a d a b$ to mean literature.

Indeed, the tradition of $a d a b$ anthologies is doubly relevant here: from its first page, Al-Finān emphasized the practical use of knowledge in a manner akin to the adab anthology; while its very title could be read as continuous with the titles of many $a d a b$ anthologies with their play on the garden of knowledge and its fruits. One could look also to the poets or the Sufis ${ }^{13}$ in tracing the multiple genealogies of these nahdawi gardens. Consider the work of Abū Manșūr 'Abd al-Malik b. Muḥammad b. Ismā'īl al-Tha'ālibī, an anthologist, critic and author writing in the shadow of Arabic prose's ascendancy in the 10th century.Tatimmat al-Yatīmah and Thimār al-qulüb fì-l-mudâf $w a-l-m a n s \bar{u} b$ attest two examples of not just an interest in gardens on a descriptive level (which abounds in classical Arabic works of poetry and prose), but of the garden and its fruits as a trope for literary production. In the former, something of a sequel to his anthology Yatìmat al-dahr, al-Tha'ālibī justifies this continuation of al-Yatimah in Tatimmah, announcing that 'it comprises witty, rare coinings and anecdotes, more pleasurable than the early basil and fresh aromatic flowers. ${ }^{14}$ In Thimār al-qulūb, as Bilal Orfali notes, al-Tha'ālibī borrows from the poet Abū al-Fath al-Bustī, in a self-deprecating 'presentation of a supposedly inferior book' ${ }^{15}$

Do not condemn [me] when I present to you the choicest from your [own] venerable sciences or bits from your [own] literary arts

Indeed, the gardener presents to the owner the precious produce from his [own] garden by virtue of his service. ${ }^{16}$

Al-Khūrī, the Bustānīs, Nimr, Șarrūf and many other nahdawī editors would continue in this metaphor, playing the role of 'the gardener' offering readers 'the choicest from your venerable sciences or bits from your literary arts.' 
Of course, there is a much older tradition of the garden at work here as well, one that resonated both in the singular jannah as well as in Buțus's pluralization of it into jinān. Not only does this evoke notions of al-jannah as paradise- be it one of Eden or the afterlife-but in the compulsion to tether al-jinān to this particular singular noun al-jannah, an anxiety is betrayed as to the other meanings lurking in the root, which elicits not only idyllic gardens, but also affairs of the heart, rapture, madness, and the jinn.

One of the primary meanings of the root $j-n-n$ is to cover, hide, or make dark, and it is to this sense that Butrus turns in the sixth volume of his encyclopedia Dảirat al-ma'arif. The entry for the fully voweled jannah begins: 'al-jannah in language is the garden [al-hadīqah] containing palms, trees and plantings [bustān] and it is called that because it shades or covers the land with its shadow. ${ }^{17}$ Moving from these earthly shadows, Butrus next turns to 'earthly paradise' (al-firdaws al-ardī), or the Garden of Eden, inviting his audience to read more about Eden under the letter 'ayn. Butrus composed this encyclopedia, beginning with alif and dying in 1883 while at work on the seventh volume, well before reaching the letter 'ayn. Neither would his son Salim live to see the Eden of $D \bar{a}^{c}$ irat al-máarif, dying the next year at the young age of 37 while at work on the eighth volume, as his brothers Najīb and Nasīb, and their cousin Sulaymān inherited the earthly responsibility of defining Eden. By 1898, nearly finished with the letter $s \bar{a} d d$, Sulaymān had finally found a publisher for the still incomplete, still Eden-less encyclopedia, announced for purchase through Jurjī Zaydān's Maktabat al-Hilāl, located in Cairo. $^{18}$

After Eden, Butrus continued in the entry on al-jannah to note that 'in all religions' aljannah is the paradise that awaits the righteous after death. He goes on to describe both the 'spiritual, mental' conception of paradise among Christians, as well as the more material, sensory garden awaiting Muslims. ${ }^{19}$ This sense of al-jannah as a paradise to be pluralized resonates with the only word in this entry written in Latin letters: 'paradis-e,' with its curiously hyphenated final letter 'e' straddling French and English. Naming his new journal Al-finān, already a plural, alongside his other newspapers Al-fannah and Al-funaynah, Butrus invited a disparate readership to imagine the garden as a plural, heterogeneous space, the necessity for the individual reader of staking a claim to a particular vision of the garden momentarily elided. Staged in its multiplicity, the gardens of the early Beirut press interpolated readers perhaps partial to quite different notions of what al-jannah could be, offering the plural as (I am arguing) in the end a rather fragile, ephemeral figuring of the private Arabic press's early moment, containing within itself the inevitability of a fall, and the specter of death in the plural, which haunted the Nahdah from its fraught beginnings.

The immediate history of this utopian moment of elision can be located in the aftermath of the events of 1860 , as Beirut went from being a minor port city eclipsed by 'Akka to the south, to a refuge for those fleeing the violence on the Mountain and in the hinterland. It was also the site of French intervention in the conflict and its aftermath, which witnessed French capital penetration in an industrializing silk economy increasingly subject to fluctuations of the world economy. As concerned about the carnage as the silk harvest of 1860, gone up in flames, over the course of the booming 1860s in Beirut, French and Syrian industrialists and bankers found in Beirut, and its surrounding mulberry orchards and growing infrastructure of finance capital and filatures, the hope of a more reliable source for raw silk cocoons and thread than the French silk industry could provide, increasingly destabilized as it was by blight and labor strikes in the south of France. A local bourgeoisie grew in wealth and influence, owners of many of the lucrative 
filatures and mulberry orchards if also indebted to French banks and local financiers and brokers who financed the purchase of silk eggs through a sophisticated silk futures market, dependent on accurate information and on honing new kinds of literacies as they navigated a now globally connected, capitalist world textile market.

Immediately prior to the 1870 periodical boom, new educational institutions appeared — such as Buțrus al-Bustānī's al-Madrasah al-wațaniyyah or the National School founded in 1863, and the Syrian Protestant College founded in 1866 by American missionaries - and Université Saint-Joseph would be founded only a few years later in 1875 by French Jesuits, many of whom, like their American missionary counterparts, were avid readers of Arabic. There was a persistent sense in Beirut from the late 1860s and through the $1880 \mathrm{~s}$ that the path to progress and civilization, the oft-professed desire that lends the nahdah its hopeful teleology, was a path that would bury the haunting nightmare of 1860 in gardens of useful knowledge and profit-bearing mulberry orchards. The readership of the Beirut press of course extended far beyond that growing Mediterranean port city and its concerns over the silk trade, reaching to the banks of the Nile and Euphrates, and the shores of the Atlantic and beyond.

As Al-Finān saw the end of its first year, its editors invited readers to imagine the contours of the gardens of literature to come. An announcement read:

It is by His great might and the protection of those overseeing important matters that Al-Finān's first year nears its end. We have attained much more than we had foreseen in terms of achievement and success, and that is the greatest proof of the progress of the Arab nation [al-ummah al-'arabiyyah], under the protection of the Sublime Porte, ever advancing to a fine stage in the stages of the age of civilization and knowledge, for many have entered the gardens of literature [jinān al-adab] and useful news by spending glittering gold and the essence of precious time in reading newspapers and writings built upon the foundations of truth and integrity and a lack of bias. Due to that, and to it being evident that those seeking Al-Finān are many and that the majority of this year's subscribers will be renewing their subscription, we have decided to continue to send Al-finān this coming year to all those who do not request that we stop doing so. That is to say that we are not requiring those who wish to renew their subscription to request that in writing or orally, but rather asking those who do not wish to renew their subscription to be so kind as to let it be known so that we can sunder them from Al-finān. And we request those who wish to subscribe for the coming year among those who have not subscribed this year be so kind as to let that be known before we enter our second year in order that we may know how many copies to print each time. And finally we ask God to grant them health and success and a long life of many years for He sees and hears and His response is just. ${ }^{20}$

There are two ways, then, in which one can be sundered from that hopeful space of Al-finān: one can inform the editors of a desire not to subscribe, to not participate in spending 'glittering gold and the essence of precious time in reading newspapers and writings'; or one can be sundered from these earthly gardens of the future by death, by the hope of a 'long life of many years' being thwarted by the divine, in an eerie augury of the far too early death of Salìm, whose hand may well have penned these words. This curious subscription policy contains within itself the possibility that those 
whose last year on earth had passed, although sundered by death, might nevertheless be receiving subscriptions to Al-Finān, haunting the gardens of the future.

The afterlife of these decades in Beirut would haunt a future Ezbekiyya after midnight, a counter-allegory in a melancholic mode ${ }^{21}$ that cannot be understood without lingering a moment longer in the gardens of Beirut, and considering the changing fate of the mulberry orchards of Mt Lebanon. In the late 19th century, Beirut's architecture went through a considerable change, as social historians Nada Sehnaoui and Leila Tarazi Fawaz chart in their studies of late-19th-century Beirut. ${ }^{22}$ As both scholars note, the bourgeoisie, many of whom comprised the audience for journals such as Al-finān, were increasingly building homes modeled on the Italian villa, with large picture windows surrounded by gardens. The whole idea was predicated on seeing and being seen, and in this sense was a radical departure from the courtyard-centered style of building traditionally favored in the region. These changes in architecture might bring to mind Timothy Mitchell's discussions of vision, space and perspective in Colonising Egypt, a book indebted to the earlier work of Janet Abu Lughod on the city of Cairo, and indeed these echoes will become quite important to a reading of the Ezbekiyya of Jurjī Zaydan's 1892 novel Asīr al-mutamahdī.

The garden as a cipher for a journal and its readers for a moment managed to straddle competing imaginings of the garden and its connotations. The garden could be that secluded space of the courtyard and its orange trees and fountain, or the gardens surrounding the bourgeois homes being built in not only Beirut's Zuqāq al-Blat but also Cairo's new quarters, with carriages and their passengers rolling by and taking in the view. Or, yet again, it could be the public gardens appearing in cities throughout the region, joining more informal spaces on the edges of cities such as Beirut, Damascus and Cairo, where families, friends, and would-be lovers might while away their days and later evenings, and where Salīm set an early scene in his first serialized novel, al-Huyām fi jinān al-Shām (Love in the Gardens of Damascus).

In the first installment of the novel, Salim writes his character Wardah, with a book in one hand and a rose in the other, into these eponymous gardens of Damascus with a group of female friends in 1868. While Wardah wishes her friends could enjoy their 'free time reading useful, literary (adabiyyah) books concerned with promoting the causes of civilization and knowledge and improving morals and strengthening the mind, ${ }^{, 23}$ we as readers are left to wonder whether this novel we have just begun, or for that matter the journal in which it is serialized, is the sort of writing Wardah has in mind. Our vantage point on this scene is through the gaze of our male narrator Sulaymān who, having already followed these women to the gardens at the edge of Damascus, wanted at the beginning of the second installment, published in January of 1870, to get still closer so as to better hear one of their voices. 'And yet,' he said to himself:

I was afraid that they would become aware of me, and so would run away from me and leave this garden [hadiqah] ... then I saw a grove of young trees behind which I could hide from their sight even as I could both hear and see them. So I advanced to a place behind that grove, and, using its branches to hide me from their eyes, I sat on the ground. My heart was beating like one fearful the sky would fall upon him. ${ }^{24}$

As Salīm al-Bustānī enframes it, our perspective on this scene of women whom we can 'both hear and see' is enabled by the shading branches of this 'grove of young trees.' 
Our narrator, ensconced behind this shading grove, confesses: 'I felt as though I was in the Garden of Eden.'

The young women are discussing how best to spend their money and their time. As Wardah praises 'useful, literary [adabiyyah] books,' Hawā', a fallen Eve in the Bustāni gardens, is revealed, despite her father's wealth, to be not only illiterate but far too fond of alcohol and make-up. Not much better in Wardah's estimation is her friend Su'adā, an avid smoker ${ }^{25}$ and a rebellious reader interested only in being entertained by the likes of Abū Nuwās, and who, if 'she had thought a given book would be of true use' to her, 'would not have allowed herself to read it. ${ }^{26}$ The garden is from the beginning then figured as both idyllic and yet also surprisingly hazy and intoxicating, abetted by the shade of trees not unlike those that would appear in the jannah of Da'irat al-máârif, an accumulation of ambiguity indexing debates over the dizzying changes rapidly reshaping the literary and economic, as well as competing visions of women's public roles in this moment. While these young women are briefly returned to a utopian vision of the garden and the press when the gardener (al-bustān $\bar{\imath}$ ) presents the women with its fruits, which they ate and then 'rose [nahadna] and went for a walk in the garden [al-bustān],' our male narrator's 'gaze never wandered from Wardah. ${ }^{27} \mathrm{~A}$ utopic garden into which women readers were invited is already, and perhaps always, troubled, and with the passage of time it appears only more so.

Sulaymān, the wealthy protagonist of al-Huyām fi jinān al-Shām who hides in this early garden scene behind a grove of trees, is revealed in issues 15 and 16 to himself be one of the many silk financiers profiting off Beirut's and Mt Lebanon's mulberry orchards. He explains his finances to the novel's enframing narrator:

My hands did not hold at that time a single dirham because my money was in the hands of the brokers. I am not saying that I practiced usury, far from it, for I hated the usurers or those who give the poor what would cover their needs and take from them much. Rather I had placed my money in the hands of those whose presence had been made necessary by the present organization of the world which has bound all that you have in the world together with commercial [tijäriyyah] relations. For they take the money from those in ease in order to widen the operations of those that, despite their being of easy circumstances, need an extension of money in order to fulfill their commercial [tijäriyyah] operations at a specific time, such as during the days of the harvest, in order to increase the amount they buy so as to increase their gain and facilitate trade [tijärah] by taking papers acknowledging the given amount in a given place in order that they collect their value at a later time than in the time in which they paid their amount and in a place other than the place in which they arranged them before. Exposing themselves to the calamities that might be produced by a lack of these pieces of paper standing in for the money that they paid for them. ${ }^{28}$

The narrative's allusion to 'calamities' references the considerable risk involved in speculating in the silk harvest not only for the brokers but also for their financiers, such as Sulaymān. While lenders attempted to secure their future returns through the guarantee of 'pieces of paper standing in for money,' it is understood that in the event of a disastrous silk harvest, all might be lost. 
Al-Finān's report on the locusts that had been ravaging the mulberry groves in its 10 th issue, published in mid-May 1870, was no doubt met with some hope by those whose assets were tied up with the year's silk harvest. It read:

The high degree of determination that was demonstrated and continues to be demonstrated by the government of [Mount] Lebanon and its inhabitants in annihilating the locusts [jarād] calls for the thanks and gratitude of all. Because were it not for this determination then the locusts would have destroyed the Mountain and the rest of the country. ${ }^{29}$

The installment of al-Huyām fĭ jinān al-Shām that appeared in this issue of Al-finān recounted the fate of Sulaymān and his entourage of foreigners after their first battle with Beduin forces following their sightseeing visit to the ancient city of Tadmur (Palmyra). While they thought that they had perhaps escaped, in fact an enormous army returns and captures them, placing the group in confinement 'after they had stripped us [jaradūn $\bar{a}$ ] of most of our clothes' ${ }^{30}$ (ba'd an jaradūnā min akthar malābisināa). Thirteen pages earlier in the same issue, readers of Al-fina $\bar{n}$ may have been comforted by the efforts expended in fighting the armies of locusts (jarād). Yet the Beduin army that returns to capture the protagonist of al-Bustānī's novel along with the rest of his group metaphorizes the feared fate of the silk harvest, laying it bare as it were. The reader recognizes the multiple layers of this metaphoric operation, not only at the level of unfolding events but also at the linguistic level, through the repetition of the root $j-r-d$, to strip or lay bare: the army of Beduin 'stripped' (jarad̄̄ ) the protagonist Sulaymān and his foreign friends of their fine clothes, just as the 'locusts' (jarād) laid bare the mulberry trees. The next issue of Al-finān makes plain this defeat, directing its readers to the economic downturn that is expected:

it is thought that the price of silk this year will not exceed the middle point, for it is heard that the harvests in Europe and especially in France were very good. It is the nature of these losses to stop the gears of trade (tijärah) which turn when the steam of the harvest's quality moves them. ${ }^{31}$

The Edenic imagined space offered by the burgeoning private Arabic press, envisioned in its early Beirut years as a garden of literature and knowledge, was predicated on the necessarily ephemeral, strategic vagaries of a utopia of editors, writers, and readers. The cultivation of this garden served also as a refuge, a position from which to register an enduring critique of the increasingly uncertain, anxious, dystopic habits of speculation that were financing and profiting off the region's mulberry orchards and silk markets. The gardens of Damascus in novels of 1870 give way to the anxiety governing Beirut's markets and the European economic capitals to which the cities of the region were increasingly tethered.

As Tarek El-Ariss underscores, Aḥmad Fāris al-Shidyāq wrote his 1863 Kashf $a l-m u k h a b b a^{\prime}$ 'an funūn Urūbā from London. For Shidyāq, London's smoke-filled business district is both the locus of his literary production and the center of financial speculation: 'in one institution alone, one could find up to 500 traders and 1000 brokers.' 'It is in this unhealthy place,' laments Shidyāq, that he 'was destined to write this book. Not in Italy's green meadows or Damascus's elegant gardens. ${ }^{32}$ In London, as in Beirut, 'Damascus's elegant gardens' and the utopian imaginings they 
engendered are subsumed by the contradictions of the world economy as the century nears its end. Anterior gardens - of paradise, of Damascus-are briefly imagined spaces set apart from the capitalist economy that was increasingly knitting Beirut and Cairo into a 19th century with its finances centered in London, and its commodity capital, as Walter Benjamin would have it, in Paris. ${ }^{33}$

In 1892, one of Al-Finān's most famous readers began to publish a literary scientific journal in Cairo. Later acknowledging his own indebtedness to the journals of $1870 \mathrm{~s}$ and 1880s Beirut, ${ }^{34}$ with a passing mention of Salīm al-Bustān̄̄, Jurjī Zaydān also that year announced his early novel $A \bar{s} \bar{r}$ al-mutamahdī (a title we might translate as 'The Captive of the Self-Made or So-Called Mahdī') for purchase in book form in 1892 in the fourth issue of his Cairo-based journal Al-Hilal. ${ }^{35}$ Inheriting Beirut's literary genealogies in a city with a rich cultural scene of its own, the plot of Asir al-mutamahdi at times seems overwhelmed by the proliferation of the Arabic press, and a staggering preponderance of gardens. ${ }^{36}$

The novel is prefaced by a brief 'historical introduction' in which Jurjī Zaydān acquaints the reader with the tremendous changes that had occurred in Cairo as of 1878, the year in which the novel begins. Focalizing on Khedive Ismāîl and his desires to make Cairo 'a piece of Europe,' we are told of Ismāîl1's efforts to:

Open [fath] modern streets and establish new, organized quarters, following which were established thousands of homes and palaces and gardens [hadāi $i q$ ] outside the original city, and wide, new streets were lined with trees on both sides, and the entire city was illuminated with gas, and its night became like its day and it grew in elegance and luxury, and public places in the city increased especially around the garden of Ezbekiyya. ${ }^{37}$

A few lines later, Zaydān describes a diverse crowd, wrapt by the spectacle of military music being played each evening beneath the gaslights in Ezbekiyya. Zaydān addresses the reader in the second person-wa-kunta idhā dakhalta al-hadīqah bi-l-masä - informing him that 'if [he] visited the garden by night,' he would find those wearing 'the Arab turban, the Ottoman $\operatorname{tarb} \bar{u} s h$, the Persian $q \bar{a} w \bar{u} q$, and the foreigner's hat. ${ }^{38}$

The first line of the novel reads:

On Shāric al-'Abbāsiyyah in 1878 there was a house built in the modern style like the other moderns homes there, but it was among the least grand and wide of them, and it had a simple small garden [hadīqah] that looked out upon the modern street shaded with ficus trees planted on both sides. ${ }^{39}$

This is the home of our protagonist Shafiq, to which his parents anxiously await his return. He has, for the first time, stayed out past dark. Just before his mother Su'adā turns to her window overlooking this 'simple small garden' and the 'modern street shaded with ficus trees planted on both sides' to worriedly pass the time until her son's arrival, she announces to her husband her desire to share with Shafiq an article she had been reading in Al-Muqtataf. Shafiq, it is widely thought, will soon be chosen by Khedive Ismāîl to study in England.

The Syrian émigré households that provide Asīr al-mutamahdī with its protagonists are avid readers of the Arabic press, and fathers, mothers, sons, daughters and servants share a particular predilection for reading periodicals published by Syrian émigrés in Egypt or in 
the Beirut they left behind, including not only Al-Muqtataf, but also Al-Ahrām, AlLată $\bar{a}^{3}$, and Lisān al-Hāal. ${ }^{40}$ Mother and daughter are also prolific letter writers, and yet their letters frequently do not make it to their destination or are read by unintended audiences, obliquely registering a sense that women's writing was not making it to its audience; this would be partially remedied in 1892 when the first women's journal Al-Fatāt began publishing in Cairo ${ }^{41}$.

This is not a novel of 1870s Beirut, however, but rather one that is haunted by the city's past. Shafiq's mother Su'dā had been distracting herself from other worries as she read Al-Muqtataf that evening. Thinking that her son was already home and in his room 'reading newspapers or something else, ${ }^{, 42}$ she herself had been anxious for the time to pass until midnight, the appointed hour when her husband would reveal the contents of a small box he had kept hidden since their wedding. Shafiq's mother now 'forgetting or appearing to forget that matter of the box'-a box that will be revealed in the novel's closing pages, in the mountains above Beirut, to contain a bloody secret of the family's Syrian genealogy and its flight to Cairo-Su'dā 'looks out the window not diverting her gaze from the street ${ }^{43}$ as the hour strikes ten o'clock, and then eleven. Her husband's efforts to comfort her, telling her 'there is no need to worry,' that 'the city is safe, and the streets are not empty of pedestrians until after midnight,' and that 'perhaps Shafiq went with his fellow students to Ezbekiyya garden to listen to the melodies of military music,' fail to calm her heart. ${ }^{44}$

While the space of the garden in early 1870s Beirut, imagined through Damascus's gardens, temporarily elided debates that would persistently trouble the future of the Arabic press, in Zaydān's Asīr al-mutamahdī, the Ezbekiyya of 1870s Cairo reads at first as an entirely un-Edenic space, as everything that had threatened Beirut's gardens with a fall. In this novel, Ezbekiyya is the site of illicit midnight encounters of wouldbe lovers behind the backs of their fathers, aided by a well-dressed literate servant. ${ }^{45}$ And it is where our protagonist Shafiq is tricked into drinking his first cognac by his undeservedly dear friend 'Azīz, in a coffeehouse in Ezbekiyya 'set up for dancing and singing.' When they arrive at this cabaret, Shafiq looks around him and sees:

People in groups and alone drinking and singing and laughing, some of them swaying with delight at the sound of song, while another calls out at the top of his voice 'āh, kamān yā sitt' - again my lady-while others toast and drink to one another.

Shafiq looked at his friend in shock saying 'Where are we 'Aziz??"46

It seems in this evening Ezbekiyya that we are somewhere far from Eden, and that the press and the novel have been reconfigured as a critique of a disorienting garden, destined to persistently connote intoxicated states, a sense of rapture, and the promise of romantic encounters.

Yet before we dismiss this 1870 s Ezbekiyya as entirely un-Edenic, we might skip ahead a few years to the first 1896 issue of $A l-H i l a ̄ l$, in which a curious Najīb Effendī Shāmī al-Ṣaydalī asks $A l-H i l a \bar{l}$ :

What was the tree from which our grandfather Adam ate in paradise [al-firdaws] and due to which he was sundered [from the garden] and which the Bible calls the tree of good and evil but does not mention by name. ${ }^{47}$ 
It is presumably Zaydān who responds in the name of Al-Hilāl to offer two rather straightforward answers: that many believe it was an apple or another sweet, delicious fruit, or that 'the story [hikāyah] of this tree is symbolic.' But then Zaydān offers a rather different account, one that harmonizes far more with Ezbekiyya after midnight than we might have expected. For Zaydān throws out the possibility that this 'tree was among the elevating or intoxicating trees that now grow in some parts of India and Africa,' reminding his readers that 'all that can be said about [the tree] is in the realm of guess and conjecture. ${ }^{48}$

Not that long before the events of the novel, in fact, Ismā'il's Ezbekiyya had itself been a garden 'in the realm of guess and conjecture.' Previously a pond fed by diverted Nile waters, by 1866 Ezbekiyya and the surrounding area were drained and filled in, ready for a wave of city planning inaugurated by Ismāêl's 1867 trip to Paris, as he envisioned a new Cairo in which to host the Suez celebration. Returning to hire 'Alī Pasha Mubārak as Minister of Public Works, maydāns were planned throughout the city, with their formal plantings joining new streets newly lined with trees in a vision of Cairo as a grand, modern city of boulevards and parks. As Janet Abu Lughod tells us, just prior to the opening of the Suez in 1869 :

Ismā $\overline{1}$ imported the French landscape architect-Barillet-Deschamps-whose work he had admired in the Bois de Boulogne and Champs de Mars and commissioned him to redesign Ezbekiah as a Parc Monceau, complete with the free-form pool, grotto, bridges and belvederes which constituted the inevitable clichés of a nineteenth century French garden. ${ }^{49}$

Beyond the public garden of Ezbekiyya and the gardens surrounding the new homes being built in Cairo along streets like Shāri' al-'Abbasiyyah, gardens abound in Asìr almutamahdi, tracing a geography not unlike Zaydān's own from 1883 to $1887 .^{50}$ During those years, Zaydān left Beirut; at first for Cairo planning to continue his medical studies at Qasr al-'Aini, although he would soon head to the Sudan as an interpreter for the British, before eventually returning to Cairo, where he would found Al-Hiläl. The many gardens he charts in Asir al-mutamahdi, one of the first novels he advertised in $\mathrm{Al}$-Hilāl, read sequentially as Zaydān's geography in reverse, save, of course, the gardens of Paradise (al-jannah) that are mentioned in one of the Mahdi's sermons to his army in Sudan. There are Ezbekiyya and the gardens lining the new streets of Cairo, some of which we have already seen; the gardens of Qasr al-Nuzhah in Shubrah, where Khedive Ismāîl and later Tawfíq would go for weekly strolls; the gardens of Khartoum; the green gardens of Beirut; the garden overlooking the Mediterranean at Dr Nūn's Beirut home (who we are told was a former member of the Syrian Protestant College medical faculty); the Hamīdiyyah public garden in Beirut by the police station; and the gardens in Mt Lebanon that are overlooked by the village of 'Ālayh. ${ }^{51}$

Serializing a chain of gardens, reaching back from Ezbekiyya to the gardens of Beirut and Mt Lebanon, a geography connected by the Nile, Suez and Mediterranean emerges. This not only traces Zaydān's life itinerary, but also plots the centrality of bodies of water to the flow of commodities, literary strategies and empires for Cairo as for Beirut, and for the riwāyāt by now flooding the Arabic press and book markets. Bodies of water are central to the events of the riwāyah at hand, Asìr al-mutamahdi. Plans to attend the opening of the Khalīg ultimately unravel, with Shafì finding himself in Ezbekiyya well 
past sunset, having attended for the first time part of a performance of a French play at the new Opera. When they first arrive at the Opera, 'Azīz asks Shafiq: 'Would you be amazed if I told you that Khedive Ismāîl built this and furnished it in five months?,' going on to detail the debts Ismāîl incurred as he 'prepared to fête the opening of the Suez Canal, ${ }^{52}$ which is used later in the novel to carry the British to the Red Sea as they embark on their Sudanese expedition.

Indeed, a centerpiece of Khedive Ismāîl's new Cairo was the area around Ezbekiyya. When Khedive Ismāîl came to power in 1863, Egypt had been at the height of a cotton boom, with prices high given the unavailability of American cotton during the Civil War. Turning the tools of irrigation to hydraulic city planning, from 1866 the Ismāîliyyah canal diverted water away from what had previously been the pond of Ezbekiyya. The next year, Ismā îl visited Paris, a trip that left a deep imprint on him as he began to conceive of a new Cairo to host the opening of the Suez Canal; even as the price of Egyptian cotton collapsed, the war in America now over. The debts Ismāîl incurred in these years remain infamous, and were an augury as to how French and British finance would inform the coming shape of Egypt's cotton industry, increasingly producing high-quality cotton fiber, now an industrial input calibrated to the needs of British textile factories, and the speculations of London's brokers and traders. These changes accrued in the garden of Ezbekiyya, pointing again to the cultivation of gardens as un-agricultural, un-industrial utopias. Ezbekiyya was in fact an Eden of contradiction, in an Egypt increasingly knitted into a capitalist world market governed by habits of speculation, hope and anticipation with an eerie knack for disappointment.

Even as it posed questions about the remainder that was to come, Zaydān's $A s \bar{\imath} r$ al-mutamahd $\bar{\imath}$ was not serialized in $A l-H i l a \bar{l}$, and indeed the serialized novel form charted an uneven course in the pages of $A l$-Hiläl. It was not until the journal's fourth year (1895/96), when Zaydān serialized Armānūsah al-Misriyyah, set in the distant past during the Arab Islamic conquest of Egypt, that novels were serialized in each issue of the by then fortnightly Al-Hilāl, a publishing practice Zaydān would later abandon. The year 1895 was also one in which calamities caused by caterpillars wreaking havoc on Egyptian cotton and Syrian silk crops regularly appear in scientific announcements and more politically minded editorials in Al-Hilāl. Yet, unlike Salīm al-Bustān̄i, in whose historical novels his own contemporary Beirut would repeatedly make an appearance in authorial asides, Zaydān increasingly distanced his novels from the economic hopes and crises of turn-of-the-20th-century Cairo. The economic seemed determined to overwhelm the novel form, however, because in the year Zaydān serialized Armānūsah in Al-Hilāl the increase in subscriptions came as a shock to Zaydān, ${ }^{53}$ pointing to the material concerns governing novel production that unsettled even as they founded the Edenic gardens of the nahdah.

The novel, it would seem, was a business, something the serialized novel dramatized with its suspenseful anticipation of 'the remainder to come.' The habits of speculation that novels published in late-19th-century Beirut and Cairo both echoed and fostered, harmonized to a surprising degree with other un-Edenic habits being debated in the Arabic press, such as prostitution, masturbation, the imbibing of intoxicants, gambling, and funding capitalist ventures with promissory notes and the promises of others. If the late-19th-century Arabic press was revenantly figured as gardens of knowledge coursing with riwāy $\bar{a} t$, it likewise depended on the habituation of addiction and speculation among readers in their other, thoroughly material role as subscribers. The indelible commercial taint that inheres not just in the Arabic novel, but indeed in a far longer history of 
storytelling stretching back at least as far as popular story cycles such as $A$ Thousand and One Nights, would continue to haunt Arabic literature for many years, and under other empires to come.

\section{Acknowledgements}

This paper is deeply indebted to the generous support of the National Endowment for the Humanities and the American Research Center in Egypt in Cairo.

\section{Notes}

1. The phrase is Benedict Anderson's. Anderson, Imagined Communities.

2. Roger Allen calls upon literary historians of Arabic narrative to 'investigate continuities alongside ruptures' in a move away from the 'developmental model' he sees epitomized 'in the way in which Muhammad Husayn Haykal's novel, Zaynab, has been evaluated.' Allen, 'Rewriting Literary History,' 253.

3. The term in this period is decisively riwayyah, offering further evidence of the limits of Charles Pellat's claims to the novel being qișsah in Arabic. On this point, see Allen, 'Narrative Genre and Nomenclature,' 213. Riwwāyāt in Arabic are figured as generic equivalents to the European literary production being translated, albeit not without their differences, both historically and otherwise. Readers of the late nineteenth century as well as our own contemporary moment could take this as an invitation to reconsider how Arabic inherits both the European novel and that genre's own indebtedness to Arabic popular story cycles, and most especially Alf laylah wa-laylah. Rastegar, 'Literary Modernity,' 359. See also Rastegar, Literary Modernity. For more on Salīm alBustānī and Jurjī Zaydān as early Arabic novelists, see Sheehi, Foundations of Modern Arab Identity; and Moosa, Origins of Modern Arabic. Fiction.

4. On the changing status of $a d a b$, see Allan, 'How Adab Became Literary.'

5. See Holt, 'Narrative and Reading Public.'

6. For the proceedings of the Syrian Scientific Society, mailed periodically in the late $1860 \mathrm{~s}$ to members, see Khuri, $\bar{A}^{`} m \bar{a} l$.

7. Profuse thanks are due to Christine Boustany, Nora Boustany, Kamran Rastegar and Christine Lindner for their help in locating biographical information regarding Adelaide. In Holt, 'Narrative and Reading Public,' I suggested that Adelaide may have been a pen name used by Salīm al-Bustānī to encourage women readers to write. Adelaide was in fact real, 'Hanrī wa Amīliyā' standing as her only published riwāyah.

8. Adelaide al-Bustān̄i, 'Hanrī wa Amīliyā,'Al-finān 13 (1870): 407.

9. Marianah Marrāsh responded to Adelaide al-Bustānī's invitation to enter the gate of Al-finān and seconded her call: 'Let us then gird ourselves with wisdom and understanding, and robe ourselves with true politeness and meakness, and be crowned with the flowers of the "jenan" of knowledge now open to us.' Translation from Jessup, Women of the Arabs, 163.

10. See some of the titles listed in Orfali, 'Sketch Map of Arabic Poetry.' I am indebted to Bilal Orfali for his research and guidance on an earlier Arabic tradition of cultivating gardens of knowledge.

11. Allen, 'Narrative Genre and Nomenclature,' 211.

12. This and several other excerpts cited in the body of this article will be included in an anthology of Nahdah texts currently in translation. El-Ariss, The Arab Renaissance.

13. Consider Abū al-Ḥasan 'Alī b. al-Hasan al-Kirmānī al-Sīrīānī’s (d. ca. 470/1077) Kitāb al-Bayād wa-l-sawād min khașā'is hikam al-ibād fì na't al-murīd wa-l-murād, an anthology of Sufi anecdotes that includes the following: 'Some of the poor said: If you see a poor [man] leave his food know that he has succumbed to thought, and if you see him return to it know that he is in the garden of knowledge [hadiqat al-ma'rifah].' Orfali and Saab, eds. Sufism, Black and White, 154. 
14. Quoted in Orfali, 'Art of the Muqaddima,' 189.

15. Ibid., 194.

16. Quoted in Ibid., 193-194.

17. B. al-Bustān̄i, Dảirat al-Ma'āirif, 559.

18. 'Dāìrat al-Ma'ârif li-1-Bustānī.' al-Hilāl 7, no. 1 (1 October 1898), 24. Jurjī Zaydān would include Dảirat al-Ma'arif among his footnoted sources in historical novels such as Fatät Ghassān (serialized in al-Hiläl's fifth year, 1896/97).

19. Ibn Jubayr, a Muslim traveler from al-Andalus visiting the gardens of Damascus in the late 12th century, is quoted to have said: 'By Allah, they spoke truth who said, "If Paradise be on earth it is Damascus without a doubt; and if it be in Heaven, Damascus is its earthly counterpart and equivalent."' Quoted in Lehrman, Earthly Paradise, 190.

20. 'Al-Jinān,' Al-finān 1, no. 22 (1870): 686-687.

21. For more on allegory, melancholy and finance capital, see Baucom, Specters of the Atlantic, especially Chapter 8 .

22. Sehnaoui, L'occidentalisation de Beyrouth; and Fawaz, Merchants and Migrants in Beirut.

23. S. al-Bustān̄i, 'al-Huyām fì jïnān al-Shām,'Al-finān 1, no. 2 (January 1870): 59.

24. Ibid., 56 .

25. See Sheehi, Foundations of Modern Arab Identity, on smoking in the works of Salim al-Bustānī.

26. S. al-Bustān̄̄, 'al-Huyām fì jinān al-Shām,' Al-finān 1, no. 2 (January 1870): 60.

27. Ibid., 61 .

28. S. al-Bustān̄̄, 'al-Huyām fì jinān al-Shām,' Al-Finān 1, no. 15 (1870): 479; and Al-Finān 1 , no. 16 (1870): 506.

29. 'Jabal Lubnān,' Al-finān 1, no. 10 (1870): 300.

30. S. al-Bustānī, 'al-Huyām fì jinnān al-Shām,' Al-finān 1, no. 10 (1870): 313.

31. 'Wilāyat Süriyyah,' Al-finān 1, no. 11 (1870): 326.

32. El-Ariss, Trials of Arab Modernity, 64.

33. Benjamin, 'Paris.'

34. See the fourth volume of Zaydān, Tārīkh ādāb al-lughah al-'arabiyyah, written in 1914 .

35. Mu'allafāt Jurjī Zaydān,' Al-Hilāl 1, no. 4 (December 1892, first edition): 192.

36. Zaydān, As̄̄r al-mutamahd̄̄ (originally by Mațba'at al-Hilāl and advertised for sale in Al-Hilal).

37. Ibid., 9.

38. Ibid.

39. Ibid., 11.

40. Notably, Al-finān does not make the list.

41. On women writers and the Arabic press in late 19th-century Egypt, see Baron, Booth and Cannon; Syria, see Zachs and Jessup.

42. Zaydān, As̄ì al-mutamahd̄̄, 12.

43. Ibid., 14 .

44. Ibid., 12 .

45. In this respect, Asìr al-mutamahdì stands as a literary augury, and a rather subdued one at that, of Ezbekiyya at the turn of the century in Muhammad al-Muwaylihị’s Hadīth ' $\bar{T} s \bar{a}$ ibn Hishām aw fatrah min al-zaman, first published serially in al-Muwaylihịìs Miṣbāh al-Sharq from 1898 through the end of the century, with the first book edition appearing in Cairo in 1907. See in particular chapter, twenty-four in al-Muwaylih Hadìth ' $\bar{I} s \bar{a} i b n$ Hishām on the umdah in the garden, and his ensuing late-night escapades in the taverns, clubs and theater encircling the garden of Ezbekiyya. Allen, A Period of Time.

46. Zaydān, Asīr al-mutamahdī, 20.

47. 'Shajarat Ādam,' Al-Hiläl 4, no. 9 (1 January 1896): 341.

48. Ibid.

49. Abu Lughod, 'Tale of Two Cities', 444.

50. See Zaydān, Yawmiyyāt riḥlah bahriyyah.

51. Zaydān, As̄ir al-mutamahdī, 39; 89; 109; 119; 121; and 145.

52. Ibid., 22. 
53. See his introduction to his third serialized novel. Zaydān, Fatāt Ghassān, Al-Hilāl 5, no. 1 (1 September 1896).

\section{Bibliography}

Abu Lughod, Janet. "Tale of Two Cities: The Origins of Modern Cairo." Comparative Studies in Society and History 7, no. 4 (July 1965): 429-457.

Allan, Michael. "How Adab Became Literary: Formalism, Orientalism and the Institutions of World Literature." Fournal of Arabic Literature 43, nos 2-3 (2012): 172-196.

Allen, Roger. "Rewriting Literary History: The Case of the Arabic Novel." Fournal of Arabic Literature 38, no. 3 (2007): 247-260.

Allen, Roger. A Period of Time: A Study and Translation of Hadith 'Isa Ibn Hisham by Muhammad Al-Muwaylihi. St Antony's Middle East Monographs No. 27, Middle East Centre. Beirut: Oxford University Computing Service, 1995.

Allen, Roger. "Narrative Genre and Nomenclature: A Comparative Study." Fournal of Arabic Literature 23, no. 3 (1992): 208-214.

Anderson, Benedict. Imagined Communities: Reflections on the Origin and Spread of Nationalism. New York: Verso, 1983.

Baron, Beth. The Women's Awakening in Egypt: Culture, Society and the Press. New Haven, CT: Yale University Press, 1994.

Baucom, Ian. Specters of the Atlantic: Finance Capital, Slavery and the Philosophy of History. Durham, NC: Duke University Press, 2005.

Benjamin, Walter. 'Paris: Capital of the Nineteenth Century.' Perspecta 12 (1969): 163-172.

Booth, Marilyn. "Woman in Islam: Men and the "Women's Press" in Turn-of-the-20thCentury Egypt.” International fournal of Middle Eastern Studies 33 (2001): 171-201.

al-Bustān̄̄, Buțrus. Dā’irat al-Ma'ārif, Vol. 6. Beirut: Al-Mața'ah al-adabiyyah, 1876.

Cannon, Byron D. "Nineteenth-Century Arabic Writings on Women and Society: The Interim Role of the Masonic Press in Cairo: al-Lataif, 1885-1895." International Fournal of Middle Eastern Studies 17, no. 4 (November 1985): 463-484.

El-Ariss, Tarek, ed. The Arab Renaissance: Literature, Culture, Media. New York: Modern Language Association Book Series, forthcoming 2014.

El-Ariss, Tarek. Trials of Arab Modernity: Literary Affects and the New Political. New York: Syracuse University Press, 2013.

Fawaz, Leila Tarazi. Merchants and Migrants in Nineteenth-Century Beirut. Cambridge, MA: Harvard University Press, 1983.

Holt, Elizabeth. 'Narrative and the Reading Public in 1870s Beirut.' Fournal of Arabic Literature 40, no. 1 (2009): 37-70.

Jessup, Henry Harris. The Women of the Arabs. New York: Dodd and Mead, 1873.

al-Khūrī, Khalīl. Way—idhan lastu bi-ifranjì, edited by Shirbil Dāghir. Beirut: Dār al-Fārābī, 2009.

Khūrī, Yūsuf Qizmā, ed. A'māl al-jamiiyah al-ilmiyyah al-Sūriyyah. Beirut: Dār al-Hamrā', 1990.

Lehrman, Jonas Benzion. Earthly Paradise: Garden and Courtyard in Early Islam. Berkeley: University of California Press, 1980.

Mitchell, Timothy. Colonising Egypt. Berkeley: University of California Press, 1991.

Moosa, Matti. The Origins of Modern Arabic Fiction. Boulder, CO: Lynne Rienner Publishers, 1997.

Orfali, Bilal. 'A Sketch Map of Arabic Poetry Anthologies up to the Fall of Baghdad.' Fournal of Arabic Literature 43, no. 1 (2012): 29-59.

Orfali, Bilal, and Nada Saab, eds. Sufism, Black and White: A Critical Edition of al-Bayād wa-1Sawād by Ab̄u al-Hasan al-Sìrjān̄ (d. ca. 470/1077). Boston: Brill, 2012.

Orfali, Bilal. 'The Art of the Muqaddima in the Works of Abū Manșūr al-Tha'ālibī (d. 429/ 1039).' In The Weaving of Words: Approaches to Classical Arabic Prose, edited by Lale Behzadi and Vahid Behmardi, 181-202. Beirut: Orient Institut Beirut, 2009.

Rastegar, Kamran. 'Literary Modernity Between Arabic and Persian Prose: Jurji Zaydan's Riwayat in Persian Translation.' Comparative Critical Studies 4, no. 3 (2007): 359-378. 
Rastegar, Kamran. Literary Modernity Between the Middle East and Europe: Textual Transactions in Nineteenth-Century Arabic, English and Persian Literatures. London: Routledge, 2007.

Sehnaoui, Nada. L'occidentalisation de la vie quotidienne à Beyrouth: 1860-1914. Beyrouth: Éditions Dar an-Nahar, 2002.

Sheehi, Stephen. Foundations of Modern Arab Identity. Miami: University of Florida Press, 2004.

Zachs, Fruma. 'From Difä al-Nisā' to Mas'alat al-Nisā' in Greater Syria: Readers and Writers Debate Women and Their Rights, 1858-1900.' International Fournal of Middle Eastern Studies 41, no. 4 (2009): 633-665.

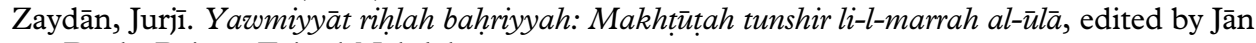
Dāyh. Beirut: Fajr al-Nahḍah, 2010.

Zaydān, Jurjīi. Fatāt Ghassān, Al-Hilal (1896-97). As̄̄r al-mutamahdī. Beirut: Dār Maktabat al-Hayāt, 2002/03.

Zaydān, Jurjī. Fatāt Ghassān, Al-Hilal (1896-97). Tārīkh ādāb al-lughah al-'arabiyyah. Vol. 4. Cairo: Dār al-Hilāl, 1957. 